\title{
Mobile Broadband for the Farmers: A Case Study of Technology Adoption by Cocoa Farmers in Southern East Java, Indonesia
}

\author{
I. Nabhani ${ }^{12}$, A. Daryanto ${ }^{1}$, Machfud $^{1}$, A. Rifin ${ }^{1}$ \\ ${ }^{1}$ Graduate School of Management and Business, Bogor Agricultural University, Indonesia \\ ${ }^{2}$ Faculty of Economics, Universitas Garut, Indonesia
}

\begin{abstract}
The objective of this paper is to examine the factors that affect Indonesia cocoa farmer intention to use mobile phone application. The main factors examined in this study are perceived usefulness (PU), perceived ease of use (PEOU), business factors and individual factors. The study sample consists of 191 respondents in thirteen cocoa farmer centers in southern East Java. Data were analyzed by employing Structural Equation Modeling (SEM). The findings revealed that the user intention on adopting mobile phone application especially by cocoa farmers is significantly impacted by social influence and this is in line with the massive growth the usage of social media application in Indonesia, other factors that determine the adoption are competitiveness pressure and cost perception. This research has a limitation that the generalizability of the findings is limited to the geographical scope of the sample. Based on findings, as the practical implications of this study, to get a higher rate on the adoption of mobile phone application, stakeholders need to ensure the benefit of technology adoption by providing more secure, more comfort, and more sounds like cloud ecosystem to increase the perception on ease of use and perception of usefulness. Novelty of this study is the combination of business factors and individual factors on the existing model of Technology Acceptance Model (TAM).
\end{abstract}

\section{Keywords}

Technology Acceptance Model (TAM), Five Forces Porter, Cocoa Farmer, Mobile Broadband, Structural Equation Modeling (SEM).

Nabhani, I., Daryanto, A., Machfud and Rifin, A. (2016) "Mobile Broadband for the Farmers: A Case Study of Technology Adoption by Cocoa Farmers in Southern East Java, Indonesia ", AGRIS on-line Papers in Economics and Informatics, Vol. 8, No. 2, pp. 111-120. ISSN 1804-1930. DOI: 10.7160/aol.2016.080209.

\section{Introduction}

The emerging growth of mobile phone application and its' utilization are enabled by the convergence of rapid growth of broadband infrastructure development and penetration of mobile phone. Some studies highlighted the positive impact of broadband development to the economic development of a country.

Globalization will accelerate the utilization rate of information and communication technology which will contribute to the economy, for every $10 \%$ increase in broadband penetration as a main infrastructure of internet will increase GDP of $1 \%$, and double increase in broadband speed will increase GDP up to $0.3 \%$. This positive impact is due to automation and simplification of the process, increase of productivity, and better access on education and health facility (ADL, 2011). Based on the study by Boston Consulting Group (2010) about economy value of internet in G-20 countries stated that internet penetration in Indonesia contribute $1.3 \%$ of total GDP in 2010 and projected to reach $1.5 \%$ of GDP in 2016 . This number is relatively lower compared to other G-20 countries which is $5.3 \%$ of total GDP, and potentially reach a higher rate if we compare to other G-20 countries achievement of average $5.3 \%$.

Indonesia is an agricultural country given the role and contribution of the sector to the economy. Daryanto (2009), as cited in Nabhani et al. (2015A), the agricultural sector has always been a mainstay in the development of the national economy despite facing greater challenges as the influence of globalization which requires the necessity of building a strong competitiveness and a specific requirement in building the competence in agrotechnopreneurship is concern and awareness 
of the e-commerce, information technology and application of the latest technology (GumbiraSaid, 2010) as cited in Nabhani et al. (2015A).

One of the seed Indonesia agriculture commodities is cocoa which put Indonesia as a top three global producer country (ICCO, 2012) and in Indonesia, this commodity plantation is dominated by farmers rather than estates or corporations (Panlibuton, 2004).

USAID (2013), in their study reported that information and communication technology help farmer in expanding their market by finding new buyers, getting the highest price and trading management, compliance, and better production management. Other benefit is access to technology and information which will expand their basic income as part of their sustainability strategy (UNDP, 2012), and according to FAO (2013), the role of information and communication technology in agriculture are better production system management, access to the market and financial institution; and cellular phone is the most favorite device use by the farmers in their social networking with other farmers or agriculture expert. It is also found that the utilization of m-commerce remain as the epicenter of ongoing digitalization of peoples' life (Pousttchi et al., 2015).

Nabhani (2015B) states that there is a possibility to explore the massive development of broadband infrastructure to give the benefit to Indonesia cocoa farmers by giving them access to a wider market and latest technology, it might increase the degree of complexity of production process but on the other hand will give them access to niche markets that appreciate a more sophisticated type of product.

Davis (1989) introduced Technology Acceptance Model (TAM) with a background of recent development on computer technology and its adoption by organization and any conducted research could not explain the resistance or acceptance on a new system. He proposed that user motivation could be explained by the following factors: perceive ease of user, perceived usefulness and attitude toward using with a hypothesis that the intention behavior is a main factor that will affect the actual system use. Somehow, this intention is influenced by two main perceptions which are perceive usefulness and perceive ease of use. These two factors were affected by the characteristic of system design represented by external variables. This study analyses the cocoa farmer's acceptance on massive mobile phone application penetration in Indonesia using the expansion of basic theory of Technology Acceptance Model developed by Nabhani (2015A).

\section{Materials and methods}

This study analyzes the farmer's acceptance on mobile phone application technology using the modified Technology Acceptance Model developed by Nabhani (2015A), a model that combined the business factors and individual factors as the latent variables that impacting user's intention on adopting new technology through Perceived Usefulness (PeU) and Perceived Ease of Use (PEOU) on introduced technology.

Based on the problem statement mentioned above, the research objective of this paper is to identify and determine the impact of business factors and individual factors that influences the adoption of mobile phone application by cocoa farmers.

\section{Literature review}

Nabhani (2015A) developed a modification of Technology Acceptance Model that initially a theory and model introduced by Davis (1989) by adding business factors and individual factors as the determinant factor of Perceived Usefulness (PeU) and Perceived Ease of Use (PEOU) that finally will impact to user's intention on adopting introduced technology.

\section{Business factors}

To define the business factors that will influence an individual/organization in technology adoption decision, this paper uses Five Forces Porter as the key variables. In order to secure their advantage in the market place, five competitive forces were those that organizations needed to heed Porter's (1979). This will include the threat of new entrants, bargaining power of customers, bargaining power of suppliers, threat of substitute products or services and jockeying among current customers. A firm need to put a plan of action in a strategy against these forces, positioning the firm with their capabilities to provide the best strategy over the competitive forces, influence the balance through strategic moves in order to improve the company's position, and anticipate shifts in the factors underlying the forces and responding to them (Porter, 1979) (see Figure 1). 


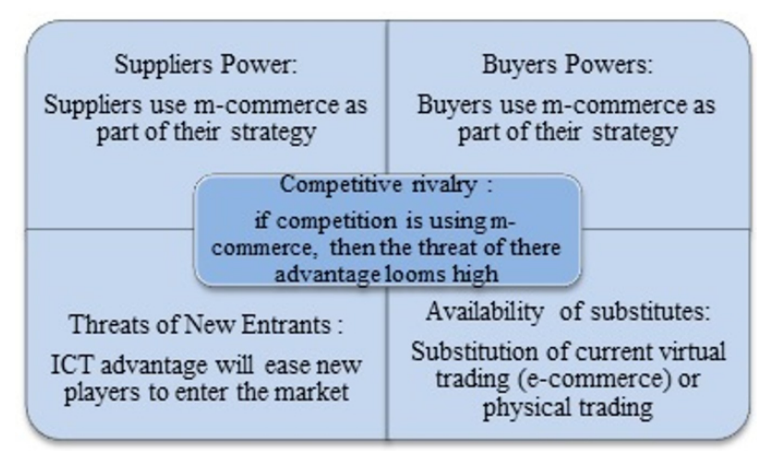

Source: Swilley, 2007

Figure 1: Mobile commerce adoption using Five Forces.

Swilley (2007) included the five forces Porter as part of business environment that were taken into account during the adoption of m-commerce with the following considerations:

- Threats of New Entrants - mobile commerce service will ease new players enter into the market.

- Power of Suppliers - if it is already adopted by the suppliers, it will become a competitive advantage to use the same communication technology.

- Power of Buyers - as adopted by the buyers, a firm need to consider to user the same technology

- Competitive rivalry - if competition is using $\mathrm{m}$-commerce, then the threat of the advantage looms high

- Availability of substitutes - is a substitute of current virtual trading (e-commerce) or physical trading

\section{Individual factors}

This paper addresses some findings from previous researches as follow:

\section{Perceived cost}

Wymer and Regan (2005) in their research concludes that from all the factors affecting the $\mathrm{m}$-commerce adoption that consistently exist across all groups was cost perception as the barrier. Khalifa and Shen (2008), combine the variables of Theory of Planned Behavior (TPB) which are subjective norm and selfefficacy into Technology Acceptance Model (TAM). Five external variables identified on the research were perceived cost, privacy, security, efficiency, and convenience. A cross-sectional survey study to $\mathrm{B} 2 \mathrm{C}$ respondents in Hong Kong was performed to test the research model. Islam (2011) in his research on m-commerce adoption in Bangladesh by mobile users used the variable of perceived cost, comprehensive and updated information, security and convenience as key factors on m-commerce adoption.

\section{Social influence}

The social influence is determined by how any human society use any new system and how it is perceived by an individual for making improvements in their living condition and status (Sadia, 2011) and most people uses any system or services because of the opinion of others or by observing different people in different situations (Davis et al., 1989)

\section{Security and convenience}

These variables were raised by Khalifa and Shen (2008), Islam (2011), Yu (2013) and Al

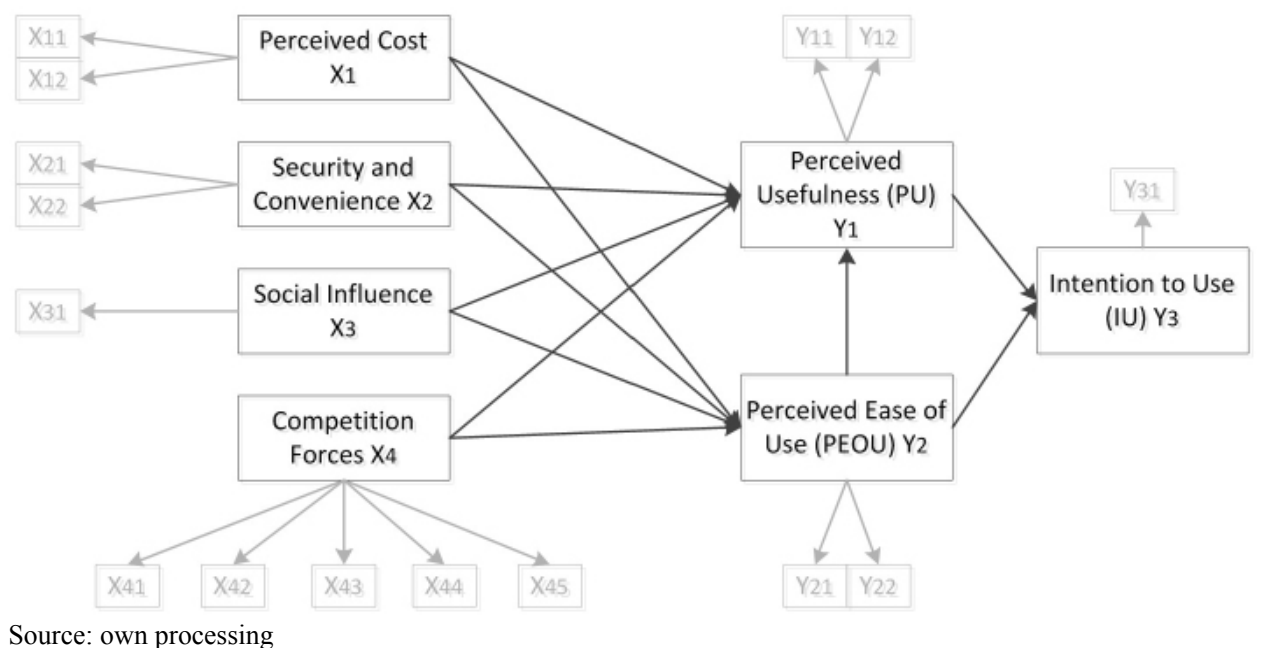

Figure 2: Conceptual framework. 
Khasawneh (2015) on their research in examining the m-commerce adoption. Security refers to the safety of exchanged information (Khalifa and Shen, 2008) especially on sensitive personal info (Yu, 2013) such as credit card number, address, and phone number, while convenience refers to the extent to which m-commerce makes easier for customers to conduct transactions compare to traditional way (Khalifa \& Shen, 2008) (see Figure 2).

\section{Research method}

This study employed descriptive quantitative data analysis. Hypotheses were developed from theoretical reviews and empirical studies. Subsequently it followed a confirmatory strategy of research in which a process of confirming or disconfirming hypotheses is employed to answer previously identified research questions.

\section{Sampling procedure}

In this study, a non-probability sampling was employed, and the sampling method used was convenience sampling. The sampling frame consisted of farmers in thirteen cocoa centers in southern East Java (Bakung, Gandusari, Kademangan, Kediri, Kesamben, Malang, Ngantang, Selopuro, Selorejo, Srengat, Trenggalek, Tulungagung, and Wonotirto). The survey method used a standardized questionnaire to collect desired information from respondents. In anticipation of a low response rate, the personal survey interviews were conducted between Octobers to December 2015. Prior to conducting a full scale survey, a pilot-test to 10 respondents was executed to solicit feedback in terms of understanding of the survey wording and evaluate the measurement reliability and validity.

\section{Operational variable and definition}

All data was generated from questioners and was designed, based and modified on previous studies.

- Intention to use. It is users' feeling on their encouragement to utilize the mobile commerce services, users' impression, prefer to interaction through m-commerce, and expect their stakeholders to use it. Adopted from Davis (1989) using Likert scale (1-5)

- Perceived usefulness. It is the level of confidence of users that the service will provide benefits to the business, work faster, more efficient, easier, more effective, and give the overall benefit. Adopted from Davis (1989) using Likert scale (1-5)

- Perceived ease of use. The level of confidence of users that the service is easy to use consist of easy to learn, easy to administer, easy to interact with, easy to become proficient, and easy to understand in overall. Adopted from Davis (1989) using Likert scale (1-5).

- Business pressure. Business pressures to adopt $\mathrm{m}$-commerce services, it means new players in the market, supplier power, buyer power, competitors with m-commerce, substitution to e-commerce service that already exists. Adopted from Swilley (2007) using Likert scale (1-5)

- Perceived cost. Perceptions about the cost of technology adoption such as the price of smart phones and internet connection tariff. Adopted from Islam (2011), Khalifa and Shen (2008), and Li et al. (2007) using Likert scale (1-5)

- Security and convenience. Level of security and convenience in doing transaction via mobile device. Adopted from Chen et al. (2013), Sadia (2011), Wei (2009), and Bigne et al. (2007) using Likert scale (1-5)

- Social influence. User adoption impacted by their community adoption on m-commerce. Adopted from Sharma and Gupta (2003), Sadia (2011) and Yu (2013) using Likert scale (1-5).

\section{Hypotheses}

This research examines the following hypothesis:

$\mathrm{H}_{1}$ : Cost perception has positive impact to perceive usefulness (PU)

H2: Safety and security have positive impact to perceive usefulness (PU)

$\mathrm{H}_{3}$ : Social influence has positive impact to perceive usefulness (PU)

$\mathrm{H}_{4}$ : Cost perception has positive impact to perceive usefulness (PU)

$\mathrm{H}_{5}$ : Cost perception has positive impact to perceive ease of use (PEOU)

$\mathrm{H}_{6}$ : Safety and security have positive impact to perceive ease of use (PEOU)

$\mathrm{H}_{7}$ : Social influence has positive impact to perceive ease of use (PEOU)

$\mathrm{H}_{8}$ : Competitiveness pressure has positive impact to perceive ease of use (PEOU)

$\mathrm{H}_{9}$ : Perceive ease of use (PEOU) has positive 
impact to perceive usefulness (PU)

$\mathrm{H}_{10}$ : Perceive ease of use (PEOU) has positive impact to intention to use (IU)

$\mathrm{H}_{11}$ : Perceive usefulness (PU) has positive impact to intention to use (IU)

\section{Results and discussion}

\section{Results}

Based on descriptive analysis on the sample's profile, this paper reveals some high level findings. Firstly, $48 \%$ of the age of cocoa farmers is above 55 years old, meaning that Indonesia cocoa is facing problem on farmer regeneration (Nabhani et al., 2015B). Secondly, in term of education level, $60 \%$ of sample are below senior highs school, Zhang (2009) concluded that the lower educational level the lower their technology adoption capability. Thirdly, based on in-depth interview with cocoa farmers association, the feasibility level of cocoa plantation will meet the scale if the plantation area is above $0.5 \mathrm{ha}$ and it is represented by $24 \%$ of sample size. Out of total 193 respondents, mobile phone penetration is $60 \%$ and smart phone penetration is $24 \%$. To gain a better insight of respondent and firm profiles, distribution frequency was used and the results are shown in table 1.

\section{Validity and Reliability Test}

The statistic procedures in LISREL were utilized on conducting the validity and reliability test. Based on the result as shown in the table 2 and table 3, it is concluded that all the indicators of both exogenous and endogenous variables in the model are valid (SLF $\geq 0.50$ dan $\mid$ tcalc $\mid>1.96$ ) and reliable $(\mathrm{CR} \geq 0.70$ and $\mathrm{VE} \geq 0.50)$.

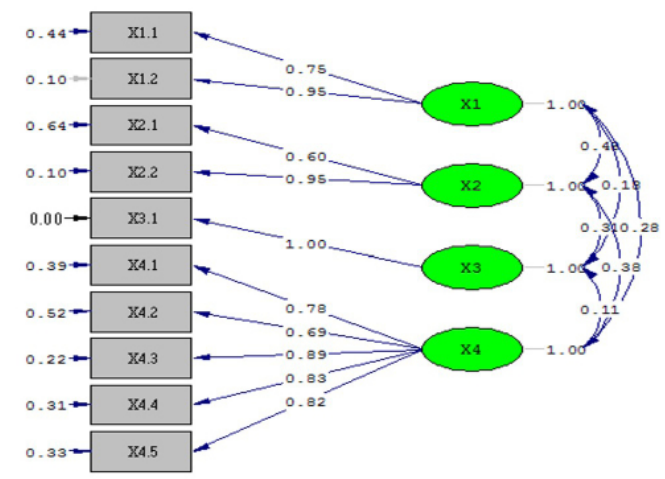

Chi-Square $=42.65, d f=29, P-v a l u e=0.04907$, RMSEA $=0.064$

Source: calculation result

Figure 3: SLF of exogenous variable in farmer's adoption model.

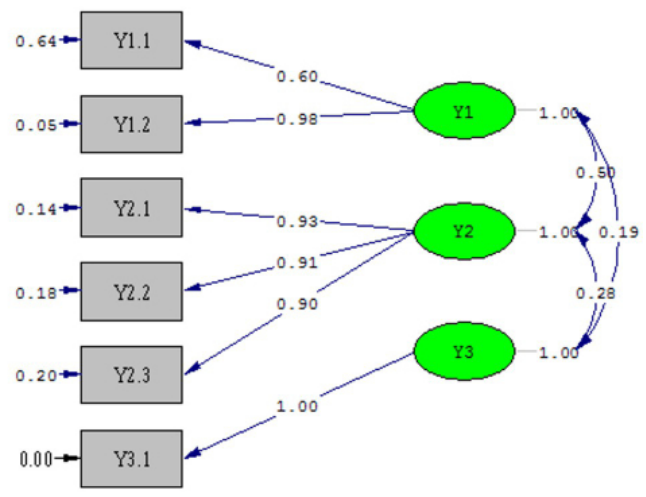

Chi-Square $=11.59, d f=7, P-$ value $=0.11494, \mathrm{RMSEA}=0.075$

Source: calculation result

Figure 4: CFA of endogenous variable in farmer's adoption model.

\begin{tabular}{|c|c|c|c|c|c|c|c|}
\hline \multicolumn{4}{|c|}{ Individual profile } & \multicolumn{4}{|c|}{ Business profile } \\
\hline & & Count & $\%$ age & & & Count & $\%$ age \\
\hline \multirow{3}{*}{ Age } & $<25$ & 16 & $8 \%$ & \multirow{3}{*}{ Year of business } & $<1$ & 5 & $3 \%$ \\
\hline & $25-55$ & 84 & $44 \%$ & & $5 . \mathrm{I}$ & 69 & $36 \%$ \\
\hline & $>55$ & 91 & $48 \%$ & & $>5$ & 117 & $61 \%$ \\
\hline \multirow{2}{*}{ Gender } & Male & 51 & $27 \%$ & \multirow{4}{*}{ Plantation area } & $<500 \mathrm{~m} 2$ & 88 & $52 \%$ \\
\hline & Female & 140 & $73 \%$ & & $500 \mathrm{~m}-0.5 \mathrm{ha}$ & 41 & $24 \%$ \\
\hline \multirow{5}{*}{ Education } & $<$ High School & 115 & $60 \%$ & & $0.5-1$ ha & 10 & $6 \%$ \\
\hline & High School & 69 & $36 \%$ & & $>1$ ha & 30 & $18 \%$ \\
\hline & Diploma & 2 & $1 \%$ & \multirow{3}{*}{ Communication device } & Feature Phone & 70 & $37 \%$ \\
\hline & Bachelor/Master & 5 & $3 \%$ & & Smartphone & 46 & $24 \%$ \\
\hline & Doctoral Degree & 0 & $0 \%$ & & No Phone & 75 & $39 \%$ \\
\hline
\end{tabular}

Source: calculation result

Table 1: Respondent profile. 


\begin{tabular}{|c|c|c|c|c|c|c|}
\hline Variable & Indicator & Loading factor & ei & Tcalc & $\mathbf{C R}$ & VE \\
\hline \multirow{2}{*}{ Cost perception } & $\mathrm{X} 1.1$ & 0.75 & 0.44 & 9.17 & \multirow{2}{*}{0.843} & \multirow{2}{*}{0.731} \\
\hline & $\mathrm{X} 1.2$ & 0.95 & 0.1 & 13.69 & & \\
\hline \multirow{2}{*}{ Security and safety } & $\mathrm{X} 2.1$ & 0.6 & 0.64 & 5.9 & \multirow{2}{*}{0.765} & \multirow{2}{*}{0.63} \\
\hline & $\mathrm{X} 2.2$ & 0.95 & 0.1 & 8.35 & & \\
\hline Social influence & $\mathrm{X} 3.1$ & 1 & 0 & 15.17 & 1.000 & 1.000 \\
\hline \multirow{5}{*}{ Competitiveness } & $\mathrm{X} 4.1$ & 0.78 & 0.39 & 9.17 & \multirow{5}{*}{0.901} & \multirow{5}{*}{0.647} \\
\hline & $\mathrm{X} 4.2$ & 0.69 & 0.52 & 8.2 & & \\
\hline & $\mathrm{X} 4.3$ & 0.89 & 0.22 & 11.79 & & \\
\hline & $\mathrm{X} 4.4$ & 0.83 & 0.31 & 11.07 & & \\
\hline & $\mathrm{X} 4.5$ & 0.82 & 0.33 & 10.44 & & \\
\hline
\end{tabular}

Source: calculation result

Table 2: Validity and reliability of exogenous variable.

\begin{tabular}{|c|c|c|c|c|c|c|}
\hline Variable & Indicator & Loading factor & ei & Tcalc & $\mathbf{C R}$ & $\mathbf{V E}$ \\
\hline \multirow[t]{2}{*}{ Perceive ease of use (PEOU) } & $\mathrm{Y} 1.1$ & 0.60 & 0.64 & 5.58 & \multirow{2}{*}{0.783} & \multirow{2}{*}{0.725} \\
\hline & $\mathrm{Y} 1.2$ & 0.98 & 0.05 & 7.60 & & \\
\hline \multirow{3}{*}{ Perceive usefulness (PU) } & Y2.1 & 0.93 & 0.14 & 12.93 & \multirow{3}{*}{0.896} & \multirow{3}{*}{0.812} \\
\hline & $\mathrm{Y} 2.2$ & 0.91 & 0.18 & 12.41 & & \\
\hline & Y2.3 & 0.90 & 0.20 & 12.20 & & \\
\hline Intention to use (IU) & Y3.1 & 1.00 & 0.00 & 15.17 & 1.000 & 1.000 \\
\hline
\end{tabular}

Source: calculation result

Table 3: Validity and reliability of endogenous variable.

\section{Path Coefficient and T-test}

The conceptual structural equation model was tested using LISREL 8.80, as shown in above table, the chi-square $\left(\chi^{2}\right)$ is equal to 101.48 with the degree of freedom (df) is equal to 70 , so that the $\chi^{2} / \mathrm{df}$ (chi-square to freedom ratio) is 1.45 which is less than the cutoff good fit $<3.0$, this indicates a good fit between the model and the collected data (Kline, 2004). As shown in table 4, seven out of eleven hypotheses received significant supports $\left(\mathrm{H}_{1}, \mathrm{H}_{2}, \mathrm{H}_{3}, \mathrm{H}_{6}, \mathrm{H}_{7}, \mathrm{H}_{9}\right.$, and $\left.\mathrm{H}_{11}\right)$, while four hypotheses where rejected $\left(\mathrm{H}_{4}\right.$, $\mathrm{H}_{5}, \mathrm{H}_{8}$ and $\mathrm{H}_{10}$ ).

\begin{tabular}{|l|c|c|c|c|}
\hline \multicolumn{2}{|l|}{ Path } & $\begin{array}{c}\text { Path } \\
\text { coefficient }\end{array}$ & T calculation & Remark \\
\hline $\mathrm{X} 1 \rightarrow \mathrm{Y} 1$ & $\gamma_{11}$ & 0.38 & 5 & Signficant \\
\hline $\mathrm{X} 2 \rightarrow \mathrm{Y} 1$ & $\gamma_{12}$ & 0.15 & 1.83 & Signficant \\
\hline $\mathrm{X} 3 \rightarrow \mathrm{Y} 1$ & $\gamma_{13}$ & -0.16 & -2.43 & Signficant \\
\hline $\mathrm{X} 4 \rightarrow \mathrm{Y} 1$ & $\gamma_{14}$ & 0.09 & 1.17 & Not Significant \\
\hline $\mathrm{Y} 2 \rightarrow \mathrm{Y} 1$ & $\beta_{12}$ & 0.16 & 1.37 & Not Significant \\
\hline $\mathrm{X} 1 \rightarrow \mathrm{Y} 2$ & $\gamma_{21}$ & 0.3 & 4.52 & Signficant \\
\hline $\mathrm{X} 2 \rightarrow \mathrm{Y} 2$ & $\gamma_{22}$ & 0.27 & 4.33 & Signficant \\
\hline $\mathrm{X} 3 \rightarrow \mathrm{Y} 2$ & $\gamma_{23}$ & -0.09 & -1.39 & Not Significant \\
\hline $\mathrm{X} 4 \rightarrow \mathrm{Y} 2$ & $\gamma_{24}$ & 0.29 & 5.9 & Signficant \\
\hline $\mathrm{Y} 1 \rightarrow \mathrm{Y} 3$ & $\beta_{31}$ & 0.14 & 0.65 & Not Significant \\
\hline $\mathrm{Y} 2 \rightarrow \mathrm{Y} 3$ & $\beta_{32}$ & 0.31 & 2.36 & Signficant \\
\hline
\end{tabular}

Note: if $\left|\mathrm{t}_{\text {calc }}\right|>1.96 \rightarrow$ significant

Source: calculation result

Table 4: Evaluation on path coefficient and tcalc.

\section{Goodness of Fit (GOF)}

Based on the GOF table calculation result as presented in table 5, all indicators indicates that the model is good and fit. The questionnaire result is able to confirm the developed theory. The model shows a good fit between the conceptual model and the data with $\mathrm{RMR}=0.044$, RMSEA $=0.063$, $\mathrm{GFI}=0.99, \mathrm{AGFI}=0.98, \mathrm{CFI}=1.00, \mathrm{NFI}=0.98$ (Designed cutoffs: RMR $\leq 0.05$ or $\leq 0.1$, RMSE RMSEA $\leq 0.08$, GFI $\geq 0.90$, AGFI $\geq 0.90$, $\mathrm{CFI} \geq 0.90$, and NFI $\geq 0.95$, Hair et al. (2010)).

\section{Discussion}

This study is performed to examine the factors (both business environment and individual) influence the acceptance criteria of the mobile phone application and in line with some recommendation from previous studies that an empirical study shall be conducted to some specific products/services in specific industries (i.e. fashion or gadget) (Yu, 2013) with more heterogeneous respondents (Zhang, 2009) with visibility to business performance post adoption (Khalifa \& Shen, 2008) (Swilley, 2007) to reveal the characteristics of specific communities in adopting new technology.

Perceive ease of use (PEOU) is positively influenced by cost perception, security \& safety, and social influence, where social influence was found to score the highest mean among other factors. 


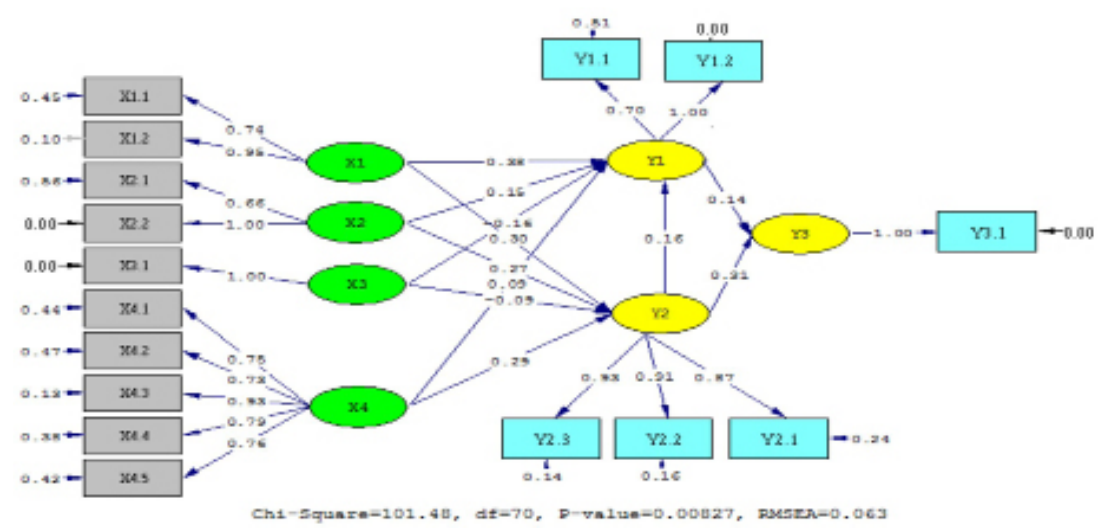

Source: calculation result

Figure 5: Standardized Loading Factor (SLF) of the model.

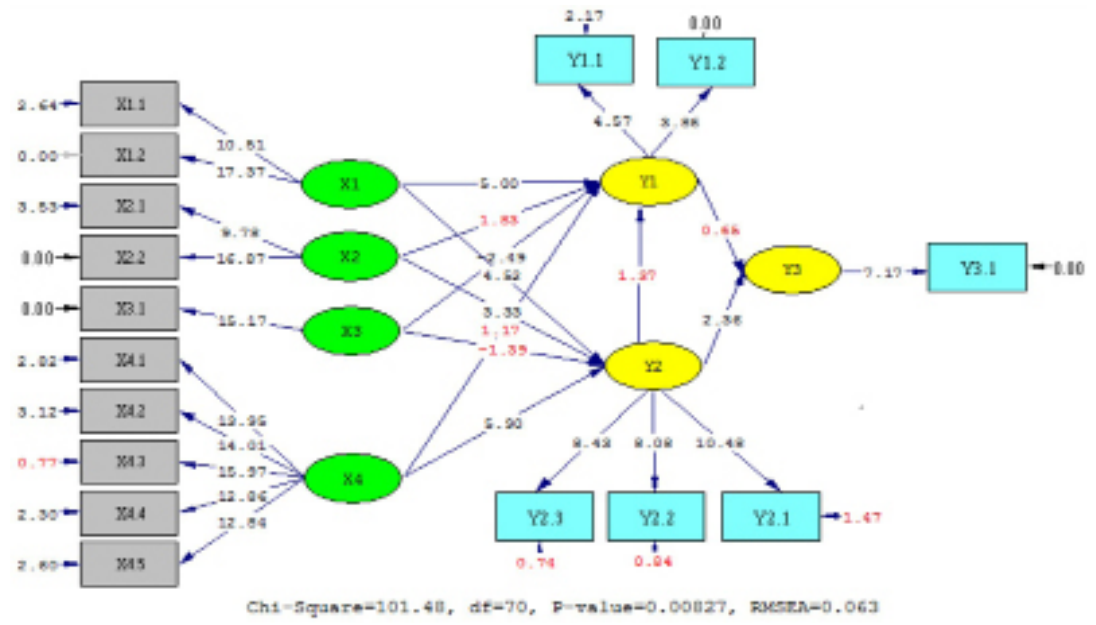

Source: calculation result

Figure 6: Tcalc of farmer's adoption model.

\begin{tabular}{|l|l|c|c|}
\hline Goodness-of-Fit & Cut-off Value & Result & Remark \\
\hline RMR(Root Mean Square Residual) & $\begin{array}{l}\leq 0,05 \text { or } \\
\leq 0,1\end{array}$ & 0.044 & Good Fit \\
\hline RMSEA(Root Mean square Error of Approximation) & $\leq 0,08$ & 0.063 & Good Fit \\
\hline GFI(Goodness of Fit) & $\geq 0,90$ & 0.99 & Good Fit \\
\hline AGFI(Adjusted Goodness of Fit Index) & $\geq 0,90$ & 0.98 & Good Fit \\
\hline CFI (Comparative Fit Index) & $\geq 0,90$ & 1 & Good Fit \\
\hline Normed Fit Index (NFI) & $\geq 0,90$ & 0.98 & Good Fit \\
\hline Non-Normed Fit Index (NNFI) & $\geq 0,90$ & 1 & Good Fit \\
\hline Incremental Fit Index (IFI) & $\geq 0,90$ & 1 & Good Fit \\
\hline Relative Fit Index (RFI) & $\geq 0,90$ & 0.97 & Good Fit \\
\hline
\end{tabular}

Source: calculation result

Table 5: Fittest criteria on the SEM model.

These findings confirmed prior empirical studies conducted by several researchers (Khalifa and Shen (2008), Islam (2013), and Sadia (2011). In contrary, social influence is insignificant as a determinant of Perceive Usefulness (PU), while other factors (cost perception, security and safety, and competitiveness pressure) are significant to Perceived Usefulness (PU).

Perceived Usefulness (PU) significantly influences 
Intention to Use (IU), while Perceive Ease of Use (PEOU) is insignificant. Interesting fact that most of respondents perceive that ease of use on mobile phone application is not determined by the competition, but they perceive that this technology is useful if their competition environment us it as part of the business which drives them to have the intention to use mobile phone application. Based on the finding in the field, most of respondents that intent to or already use mobile phone application prefers to get benefit on access to information such as update commodity price and technology as other players in the industry may do it.

In term of theoretical implications, it can be considered that the major novelty in this research is the intention to explore the adoption of mobile phone application comprehensively. This study extends the current literature in two areas. Firstly, this research used a basic version of the TAM with the combination of business environment factors and individual factors (Nabhani et al., 2015B). Secondly, this paper also examine the impact of adoption to their business performance, existing smartphone users agree that the extend utilization of mobile internet in their business improve their overall business performance.

Managerial implications on this study, based on the result of this research and past studies literature review about the different factors effecting the m-commerce adoption, this paper suggest that the supporting industry along the value chain (infrastructure provider, device manufacturer and retailer, and application developer) should try to make their services better by creating an ecosystem of mobile phone application in general (Zhang et al., 2002). The three main pillars in internet ecosystem are telecommunication network infrastructure, device penetration, and supported by application. By bringing those together, it will make the mobile phone transaction become easier and useful. This will increase the awareness about those services and will push their customer loyal to their services in accepting and adopting this technology for a long term period. These stakeholders also need to campaign the benefit of technology adoption to increase the customer awareness. Community based approach is another primary consideration in deploying this application. Individual or organization which has intention to adopt this technology should assess the projected benefit and ease of use of $\mathrm{m}$-commerce in their business. Government intervention absolutely is a necessary to push optimum utilization of broadband for the benefit of farmer in Indonesia (Stoica et al., 2005).

\section{Conclusion}

This study employs a non-probability sample of cocoa farmers in southern East Java. The decision to use convenience sampling was chosen due to the respondent's availability during the survey. This method may limit the generalizability of the results of this study. Since this study only examines the mobile phone application usage at farmer level, future research that includes more sample size on trader (local trader, district trader, and exporter) will enhance our understanding in this specific industry. Secondly, the fact from culture perspective that people in East Java is tend to be more communal, it will be better to put a cultural perspective as part of variable on the determinant of technology adoption (Frolick and Chen, 2004). Finally, future research in different sub-sectors of agriculture will broaden our perspectives on the importance of broadband/internet adoption, thus could give us better insight of how broadband/internet adoption could have different or the same impacts across different industries with the inclusion of other factors such as environmental and technological evolution (Alfahl et al., 2012).

Corresponding author:

Irfan Nabhani

Graduate School of Management and Business, Bogor Agricultural University, Indonesia

Jl. Raya Pajajaran, Bogor - Indonesia 16151

Phone: +62816800466, E-mail: irfan@nabhani.org

\section{References}

[1] Alfahl, H., Sanzogni, L. and Houghton L. (2012) "Mobile Commerce Adoption in Organization: A Literature Review and Future Research Directions", Journal of Electronic Commerce in Organization, Vol. 10, No. 2, pp. 78. DOI: 10.4018/jeco.2012040104. 
[2] Al Khasawneh, M. H. (2015) "An Empirical Examination of Consumer Adoption of Mobile Banking (M-Banking) in Jordan”, Journal of Internet Commerce, Vol. 14, No. 3, pp. 341-362. DOI:10.1080/15332861.2015.1045288.

[3] Arthur D. Little [ADL] (2011) New study quantifies the impact of broadband speed on GDP [Online]. Available: http://www.ericsson.com/news/ 1550083 [Accessed: 19 Oct 2013].

[4] Bigne, E., Ruiz, C. and Sans, S. (2007) "Key Drivers of Mobile Commerce Adoption. An Exploratory Study of Spanish Mobile Users", Journal of Theoretical and Applied Electronic Commerce Research, Vol. 2, No. 2, pp. 48-60. ISSN 0718-1876.

[5] Boston Consulting Group (2010) „Socio-economic impact of allocating 700MHz band to mobile in Asia Pacific". [Online]. Available at http://www.gsma.com/spectrum/wp-content/ uploads/2012/03/27796700impactof70022oct10egsin.pdf [Accessed: 15 Jan 2015].

[6] Davis, F. D., Bagozzi, R. P. and Warshaw, P. R. (1989) „User Acceptance of Computer Technology: A Comparison of Two Theoritical Models“, Journal Management Science, Vol. 35, No. 8, pp. $982-1002$.

[7] Chen, J. Q., Zhang, R. and Lee, J. (2013) "A Cross-Culture Empirical Study of M-commerce Privacy Concerns", Journal of Internet Commerce, Vol. 12, No. 4, pp. 348-364. DOI:10.1080/15332861.2013.865388.

[8] Food and Agricultural Organization of The United Nations [FAO] (2013) „ICT uses for inclusive agricultural value chains". Rome (IT). [Online] Available at http://www.fao.org/docrep/017/ aq078e/aq078e.pdf [Accessed: 21 Jan 2016].

[9] Frolick, M. N. and Chen, L-D. (2004) “Assessing M-Commerce Opportunities”, Information Systems Management, Vol. 21, No. 2, pp. 53-61. DOI: 10.1201/1078/44118.21.2. 20040301/80422.8.

[10] International Cocoa Organization [ICCO] (2012) „The Future of the World Cocoa Economy: Boom or Bust?" The World Cocoa Conference, 2012 November, pp. 19-23. Abidjan. Cote d'Ivoire. [Online] Available: http://www.fao.org/fileadmin/user_upload/bodies/CCP_69/ .../3a_ICCO_Presentation. pdf [Accessed: 31 Jan 2015].

[11] Islam, M. A., Khan, M. A., Ramayah, T. and Hossain M. M. (2011) „The Adoption of Mobile Commerce Service among Employed Mobile Phone User in Bangladesh: Self-efficacy as A Moderator“, Journal International Business Research, Vol. 4, pp. 80-89. E-ISSN 1913-9012.

[12] Khalifa, M. and Shen, K. N. (2008) „Explaining the adoption of transactional B2C mobile commerce“, Journal of Enterprise Information Management, Vol. 21, pp. 110-124. DOI $10.1108 / 17410390810851372$.

[13] Kline, R. B. (2004) „Principles and practice of structural equation modeling", $2^{\text {nd }}$ ed., New York: Guildford.

[14] Li, Y., Fu, Z. T. and Li, H. (2007) "Evaluating factors affecting the adoption of mobile commerce in agriculture: An empirical study", New Zealand Journal of Agricultural Research, Vol. 50, No. 5, pp. 1213-1218. DOI: $10.1080 / 00288230709510404$.

[15] Pousttchi, K., Tilson D., Lyytinen, K. and Hufenbach, Y. (2015) "Introduction to the Special Issue on Mobile Commerce: Mobile Commerce Research Yesterday, Today, Tomorrow-What Remains to Be Done?", International Journal of Electronic Commerce, Vol. 19, No. 4, pp. 1-20. DOI:10.1080/10864415.2015.1029351.

[16] Nabhani, I., Daryanto, A., Machfud, Y. and Rifin, A. (2015A) „Can Indonesia Cocoa Farmers Get Benefit on Global Value Chain Inclusion? A Literature Review“, Journal of Asian Social Science, Vol. 11, No. 18, pp. 1-7. DOI: http://dx.doi.org/10.5539/ass.v11n18p288.

[17] Nabhani, I., Daryanto, A., Machfud, Y. and Rifin A. (2015B) „M-Commerce Adoption and Performance Improvement: Proposing a Conceptual Framework", International Journal of Economics, Commerce and Management, Vol. 3, No. 4. ISSN 23480386. 
[18] Panlibuton, H. and Meyer, M. (2004) Value Chain Assessment: Indonesia Cocoa. Accelerated Microenterprise Advancement Project. Report\#2 [Online] Available: http://pdf.usaid.gov/pdf_docs/ Pnadh789.pdf [Accessed: 21 Jan 2016].

[19] Porter, M. E. (1979) „How Competitive Forces Shape Strategy“, Harvard Business Review, March-April, pp. 137-145. ISSN · 0017-8012

[20] Sadia, S. (2011) „User Acceptance Decision towards Mobile Commerce Technology: A Study of User Decision about Accepatance of Mobile Commerce Technology“, Interdisciplinary Journal of Contemporary Research in Business, Vol. 2, pp. 535-547. ISSN 2073-7122.

[21] Sharma, S. K. and Gupta, J. N. D. (2003) "Socio-Economic Influences of E-Commerce Adoption", Journal of Global Information Technology Management, Vol. 6, No. 3, pp. 3-21. DOI:10.1080/1097198X.2003.10856353.

[22] Stoica, M., Miller, D. W. and Stotlar, D. (2005) "New Technology Adoption, Business Strategy and Government Involvement: The Case of Mobile Commerce", Journal of Nonprofit \& Public Sector Marketing, Vol. 13, No. 1, pp. 213-232. DOI:10.1300/J054v13n01_12.

[23] Swilley, E. (2007) „An Empirical Examination of the Intent of Firms to Adopt Mobile Commerce as a Marketing Strategy“ [dissertation]. Florida State University. UMI Number: 3301599.

[24] Theingi, T. and Purchase, S. (2011) "How exporters' and intermediaries' resources influence export performance", Australasian Marketing Journal, Vol. 19, No. 2, pp. 100-107. DOI:10.1016/j.ausmj.2011.03.002.

[25] United Nations Development Programme (2012), „Promoting ICT based agricultural knowledge management". No. 03/2012 [Online] Available at: http://www.undp.org/content/dam/ethiopia/docs/. uralknowledgemanagementtoincreaseproductionandproductivityof0smallholderfarmersinEthiopia. pdf [Accessed: 11 Jan 2016].

[26] United States Agency for International Development (2013) „Using ICT to Enhance Marketing for Small Agricultural Producers“, Briefing Paper May 2013. [Online] Available at: https://agrilinks. $\mathrm{org} / \mathrm{sites} / \mathrm{default} / \mathrm{files} / \mathrm{resource} / \mathrm{files} /$ Using_ICT_to_Enhance _Marketing_for_Small_Agricultural_ Producers.pdf [Accessed: 31 Mar 2016].

[27] Wei, T. T., Marthandan, G., Chong, A.Y. L., Ooi, K.,B. and Arumugam, S. (2009) „What drives Malaysian m-commerce adoption? An empirical analysis“, Industrial Management \& Data System, Vol. 109, No. 3, pp. 370-388. DOI 10.1108/02635570910939399.

[28] Wymer, S. A. and Regan, E. A. (2005) "Factors Influencing e-commerce Adoption and Use by Small and Medium Businesses", Electronic Markets, Vol. 15, No. 4, pp. 438-453. DOI: $10.1080 / 10196780500303151$.

[29] Yu, Y. W. (2013) „Exploring Factors Influencing Consumer Adoption on Mobile Commerce Services“, The Business Review Cambridge. Vol. 21, pp. 258-265. ISSN 1553 - 5827.

[30] Zhang J. (2009) "Exploring Drivers in the Adoption of Mobile Commerce in China", Journal of American Academy of Busines, Vol. 15, No. 1, pp.64-69. ISSN 1540 - 7780.

[31] Zhang, J. J., Yuan, Y. and Archer, N. (2002) "Driving Forces for M-Commerce Success", Journal of Internet Commerce, Vol. 1, No. 3, pp. 81-104. DOI: 10.1007/0-306-47548-0_4. 